\title{
Comprehensive assessment of the mined coal quality and mining conditions in the Western Donbas mines
}

\author{
Dmytro Malashkevych ${ }^{1 *}$, Serhii Poimanov ${ }^{1}$, Serhii Shypunov ${ }^{2}$, and Mykola Yerisov ${ }^{3}$ \\ ${ }^{1}$ Dnipro University of Technology, Department of Mining Engineering and Education, \\ 19 Yavornytskoho Ave., 49005 Dnipro, Ukraine \\ ${ }^{2}$ Dnipro University of Technology, Department of Oil-and-Gas Engineering and Drilling, \\ 19 Yavornytskoho Ave., 49005 Dnipro, Ukraine \\ ${ }^{3}$ Dnipro University of Technology, Department of Automobiles and Automobile Economy, \\ 19 Yavornytskoho Ave., 49005 Dnipro, Ukraine
}

\begin{abstract}
The presented work reveals the problem of worsening the quality of mined coal in the Western Donbas mines. The main indicators of the stope faces performance in the context of the produced thermal coal quality are analyzed. The tendencies have been set of changes in the operational and parent ash content of coal, the number of longwall faces working with out-of-seam dilution and the production output of raw coal in the Western Donbass mines. Using the example of the "Named after Heroiv Kosmosu" mine, the coal-bearing rocks of the mined seams have been analyzed in detail, as well as the operational ash content of the produced coal has been predicted. Within the contoured reserves boundaries of the new longwall faces extraction panels, the following characteristics are analyzed: geological thickness of coal seams $m_{g}$, height of out-of-seam dilution of side rocks $h_{r}$; coal cutting resistance $A_{p}$; physical and mechanical properties of rocks in the roof and bottom of the seams. Based on the studied mining-and-geological characteristics of the stope faces under consideration, the possibility of using selective mining technology is assessed. Graphs of changes in the predicted operational ash content of mined coal are plotted depending on the possible schemes of the seams mining and the size of out-of-seam dilution of rocks. The research results can be used when planning the selective mining technology aimed at improving the efficiency and environmental friendliness of mining operations.
\end{abstract}

\section{Introduction}

Recently, there has been a worldwide tendency towards improving the quality of commercial coal, especially in connection with the stringent environmental standards for thermal power generation, introduced in many countries. At the same time, despite the advantages of generating electricity from renewable sources, the share of coal in the global

\footnotetext{
*Corresponding author: malashkevychnmu@gmail.com
} 
energy balance remains significant - 26\% [1 - 3] and according to experts [4-6], it will occupy this key position for a long period of time. Fossil coal is favored by the use of new thermal power plants in advanced countries with technologies that provide virtually zero carbon dioxide emissions, requiring high quality coals for their operation [7 - 9]. Therefore, for consumers of thermal coal, in the conditions of minimizing environmental damage, the mined coal quality indicators are of paramount importance.

Among the majority of different coal quality indicators, the ash content in the mined rock mass significantly affects the production costs and competitiveness of coal products. So, for example, with the existing system of additives, for a decrease in ash content by $1 \%$, the selling price of mined coal increases on average by $2.5 \%$ [10]. Evaluating these data on the scale of the Ukrainian coal industry, a 1\% decrease in the ash content of coal will lead to an increase in the sold products cost by more than $\$ 65$ million per year. At the same time, the additional income received from the sale of products can be directed to the modernization of coal mining and power generating enterprises in our country.

However, when mining coal deposits in Ukraine, especially in the Western Donbas, the quality of the mined coal leaves much to be desired. Often, the operational ash content of mined coal is $42-45 \%$, and in some mines even $50 \%$ [11]. The main reason for the high ash content of mined coal is the complete mining of coal and out-of-seam dilution of rocks during mining of very thin coal seams. As a result, the operating costs for mining, transportation and processing of high-ash coal increase, and the environment near mines and processing plants is polluted [12].

In the context of this problem, many scientific schools around the world are developing the "green" technologies for coal mining aimed at reducing the volumes of waste generation and pollutants emission into the atmosphere, as well as improving the energy quality of coal products. In particular, a number of recent publications are devoted to improving the mined coal quality and reducing its losses [13-15]. The works of the authors [16-18] are aimed at finding a better technology for stope works. In the works $[19-20]$, it is proposed to use the processes of rock mass beneficiation underground. A number of works aimed at creating advanced technologies for selective coal mining, excluding coal clogging by out-of-seam dilution of rocks during mining, is of particular note [21-24].

At the same time, the choice of a rational stope technology and the substantiation of its parameters largely depends on the qualitative composition of coal seams and mined coal in the mining conditions of the enterprise operation [25 - 27].

In this regard, the main purpose of the work is a comprehensive assessment of the mined coal quality and the structure of coal-bearing rocks in the stope faces of the Western Donbass mines. This can be used to substantiate the parameters of a rational technology aimed at improving the efficiency of the stope works, cost-effectiveness and environmental friendliness of mining operations.

In order to more fully assess the importance of improving the mined coal quality, it is necessary to consider this issue against the background of the performance analysis of coal mining enterprises in the Western Donbas. Therefore, the main performance indicators are given below of the stope faces in the studied region mines in terms of the quality of produced thermal coal.

\section{Analysis of the stope faces performance efficiency of the Western Donbas mines in terms of the mined coal quality}

Currently, PJSC "DTEK Pavlohradvuhillia" mines are the flagship of the Ukrainian coal industry, which annually extract more than $70 \%$ of all Ukrainian coal (18.2 million tons in 2019) [28]. At the same time, despite the difficult mining conditions in the Western 
Donbas, which are characterized by the low thickness of the mined seams and their high gas content, the load on the stope faces reaches 3.0 - 4.0 thousand tons/day [29]. However, despite high production rates, the mined coal quality has deteriorated significantly in recent years.

Analysis of the production performance of the Western Donbas mines shows that over the past 10 years, the operational ash content of mined coal has increased by $3.5 \%$ and is $44.3 \%$. For comparison, the parent ash content of the mined seams remains practically constant and varies within a small range from 11.7 to $12.9 \%$. Under these conditions, the excess of the operational ash content over the parent one was $32.3 \%$ or more by 3.7 times in 2019.

A significant increase in the operational ash content of mined coals is caused by a number of reasons, the main of which is an increase in the output volume from longwall faces working with out-of-seam dilution of rocks. Moreover, the total number of such longwall faces increases every year. Thus, in 2019, there were 19 longwall faces in operation, working with out-of-seam dilution.

The faces were in operation, in which the ash content of the rock mass reached $50 \%$ or more, while the seam parent ash content was only $8-12 \%$. It should be added that more than $90 \%$ of output of the Western Donbas mines is produced from longwall faces, working with out-of-seam dilution of side rocks, which entails a steady dynamics of growth in the ash content of the mined rock mass. The greatest dilution of the mined coal is observed in the following mines: "Named after Heroiv Kosmosu" - 50.0\%; "Blahodatna" - 49.2\%; "Pavlohradska" - 48.9\%.

Fig. 1 shows the graphs of changes in the operational and parent ash content of coal, the ratio of number of the longwall faces working with out-of-seam dilution to their total number and the output volumes of raw coal in the Western Donbas mines by years.

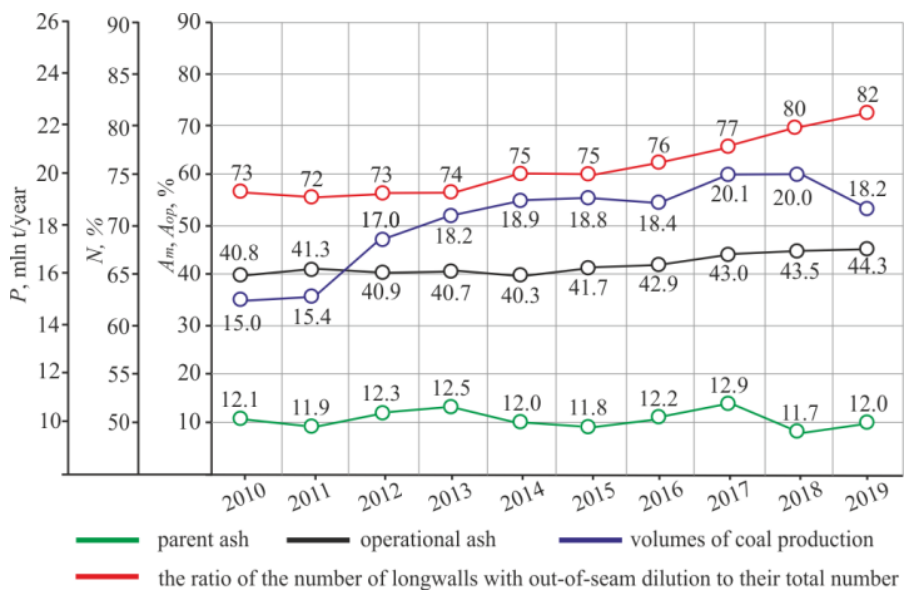

Fig. 1. Graphs of changes in the operational and parent ash content of coal, the ratio of number of the longwall faces working with out-of-seam dilution to their total number and the output volumes of raw coal in the Western Donbas mines by years.

Out-of-seam rocks dilution in the stope faces is a forced measure, which is conditioned by the lack of mechanized stope complexes of appropriate standard sizes for mining out thin seams. The overall dimensions of modern domestic and foreign stope equipment do not allow to fit into the mined seam thickness less than $0.9 \mathrm{~m}$. At the same time, as the practice shows of mechanized complexes operation in the mining-and-geological Western Donbas conditions, the minimum mineable thickness in the longwall faces should be at least $1.05 \mathrm{~m}$. 
This value provides the necessary cross-section in the longwall face for its ventilation, allows to create quite acceptable working conditions for workers in the stope face and allows the necessary flexibility of the support, excluding its landing on a "rigid base".

At the same time, the average geological thickness of the mined seams in the Western Donbass mines is $0.81 \mathrm{~m}$. Thus, the average out-of-seam dilution in the faces is $0.24 \mathrm{~m}$ or $22.8 \%$ of the extraction seam thickness.

In some cases, out-of-seam dilution in mines reach $30-40 \mathrm{~cm}$. For example, in the "Pavlohradska" mine, in 109 longwall face, a $C_{1}$ seam was mined with a geological thickness of only $0.64 \mathrm{~m}$. The coal extraction, roof fastening and control was conducted using the 1 KD80 mechanized complex. In "Named after Heroiv Kosmosu" mine, the $C_{9}$ seam with a geological thickness of $0.74 \mathrm{~m}$ was mined and the operational ash content of the coal supplied from the longwall face was $50.4 \%$, which is by $40.2 \%$ more than the parent ash content.

In 2019, 26 extraction panels were mined. Research into the stope faces operation has revealed that 6 longwall faces operated in the geological thickness range of $0.60-0.79 \mathrm{~m}$, 8 longwall faces mined the seams with a thickness of $0.80-0.89 \mathrm{~m}, 5$ longwall faces mined the seams with a thickness of $0.90-0.99 \mathrm{~m}$. The rest 7 longwalls carried out mining practically without out-of-seam rocks dilution in seams with thickness from 1.0 to $1.22 \mathrm{~m}$. The $C_{6}$ seam with a thickness of $1.22 \mathrm{~m}$, developed by the "Yuvileina" mine, is characterized by the highest geological thickness. The actual operational ash content of the coal supplied from the stope face was $13.6 \%$.

It should be noted that the main range of the extraction thickness in longwall faces is within $1.0-1.09 \mathrm{~m} .18$ longwall faces were mined within the ranges of such thicknesses. The remaining 8 longwall faces were mined with the extraction thickness from 1.1 to $1.3 \mathrm{~m}$. Moreover, in the "Pavlohradska" mine, when mining the $C_{4}+C_{4}{ }^{b}$ seam with a geological thickness of $0.9 \mathrm{~m}$, the extraction thickness in the longwall face reached $1.3 \mathrm{~m}$. The increase in the extraction thickness was caused by a large convergence of soft roof rocks in the stope face.

The histograms of the longwall faces number distribution according to the ranges of geological and extraction thickness in the Western Donbas mines are shown in Fig. 2.

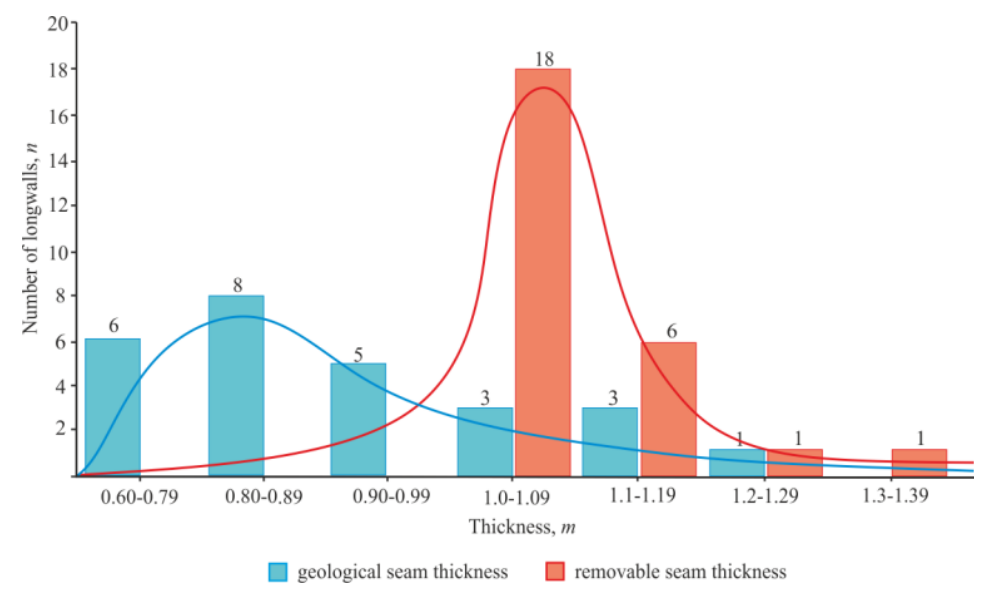

Fig. 2. Histograms of the longwall faces number distribution according to the ranges of geological and extraction thickness in the Western Donbas mines.

Also, the typical reasons for the dilution of coal mined in longwall faces include the roof rocks collapse, which often occurs during the movement of the powered support 
sections, the transitions of geological disturbances, as well as during the mining of coal seams having rock interlayers and inclusions. In the general structure of forming the general mine operational ash content, these factors occupy up to $15 \%$, however, they cannot be managed with the appropriate quality using known technical means and organizational methods.

From a technical point of view, it is easiest to reduce the percentage of out-of-seam dilution and control this value using the advanced technology of selective coal mining and out-of-seam dilution of rocks, which provides "clean coal mining" with operational ash content close to the parent ash content.

As shown by the analysis, during mining of very thin coal seams in the Western Donbas, up to $40 \%$ of the obtained rocks volume is formed from out-of-seam dilution in the stope faces. Thus, there is a significant reserve for reducing the dilution of the mined coal and, accordingly, the formation of waste rocks during the stope faces operation.

\section{Analysis of coal-bearing rocks and prediction of the mined coal quality in the stope faces put into operation}

Improving the quality of mined coal in seams less than $0.9 \mathrm{~m}$ thick is possible by using progressive technological schemes for selective mining of coal and out-of-seam dilution of rocks. The application of the selective mining technology of coal seams, the choice of its rational parameters and production processes are assessed by the following characteristics: the geological thickness of coal seams $m_{g}$ and height $h_{r}$ of out-of-seam dilution of side rocks; coal cutting resistance $A_{p}$; the stability of the immediate roof and the strength of the bottom.

This list is used, for example, when choosing the order of extraction of a coal band and out-of-seam dilution of rock layers (combined or sequential order of mining), determining the rational location of the out-of-seam dilution relative to the seam (in the roof or bottom of the seam), etc.

Let us analyze the qualitative composition of coal seams and assess the predicted operational ash content of mined coal for mining-geological and mining-technical conditions of the stope faces operation in the "Named after Heroiv Kosmosu" mine.

For the analysis, the stope faces planned for production are accepted: 1121 longwall face of the $C_{11}$ seam; 1018 longwall face of the $C_{10}{ }^{t}$ seam; 961 longwall face of the $C_{9}$ seam.

The coal seams $C_{11}, C_{10}{ }^{t}$ and $C_{9}$, developed by the "Named after Heroiv Kosmosu" mine, have flat bedding $\left(3-4^{\circ}\right)$. The grade of the coal produced is DG. The seams structure is simple. Structural columns of coal seams are shown in Fig. 3.

The composition and structure of the host rocks in the area of the $C_{11}$ seam propagation within the boundaries of the extraction panel contour of the 1156 longwall face are as follows.

The immediate roof of the seam is represented by sandstone with a thickness of 0.25 to $5.7 \mathrm{~m}$, argillite $0.4-7.5 \mathrm{~m}$ and siltstone $0.65-2.2 \mathrm{~m}$. The ultimate compressive strength $\sigma_{c s}$ for sandstone averages $31.4 \mathrm{MPa}$, for argillite $\sigma_{c s}-11.2 \mathrm{MPa}$, siltstone $\sigma_{c s}-16.3 \mathrm{MPa}$, respectively. The main part of the immediate roof of the seam belongs to insufficiently stable rocks and $30 \%$ is unstable rocks area. In terms of load properties, the immediate roof is easily collapsed.

The main roof is represented by interlayers of argillites, siltstones and sandstones with the same physical and mechanical characteristics as the immediate roof. The friable roof during the seam mining is propagated over the entire area with a thickness of up to $0.15 \mathrm{~m}$.

The bottom of the seam is represented by argillite, up to $0.5 \mathrm{~m}$ thick, with an ultimate compressive strength of up to $10 \mathrm{MPa}$. Siltstones and sandstones occur below the argillite. The ultimate compressive strength $\sigma_{c s}$ of argillites on average is $18.2 \mathrm{MPa}$, siltstones $\sigma_{c s}-$ 18.5 $\mathrm{MPa}$, sandstone $\sigma_{c s}-31.9 \mathrm{MPa}$. 
Within the extraction panel boundaries of the 1068 longwall face and along the seam $C_{10}{ }^{t}$, the immediate roof is represented by argillite $(1.2-5.6 \mathrm{~m})$, siltstone up to $1.3 \mathrm{~m}$ thick and sandstone - up to $1.2 \mathrm{~m}$. The ultimate compressive strength of argillite $\sigma_{c s}$ is $15.6 \mathrm{MPa}$, siltstone $\sigma_{c s}-24.0 \mathrm{MPa}$, sandstone $\sigma_{c s}-35.0 \mathrm{MPa}$.
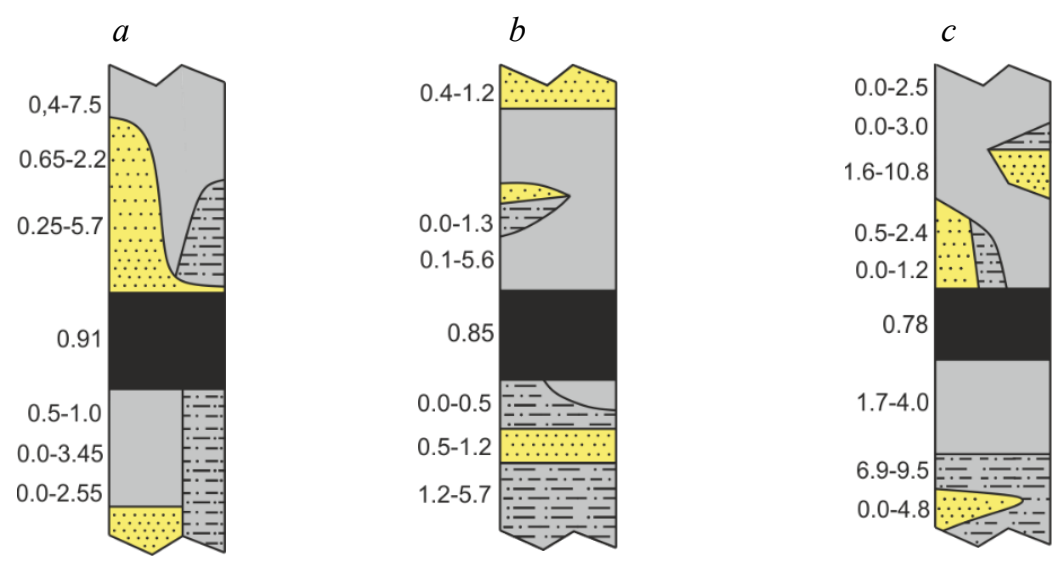

Fig. 3. Structural columns of coal seams mined in the "Named after Heroiv Kosmosu" mine: $a$ - seam $C_{11} ; b-\operatorname{seam} C_{10}{ }^{\mathrm{t}} ; c-$ seam $C_{9}$.

The main roof is composed of argillites and siltstones and, more rarely, sandstone. In terms of load properties, it is easily collapsed. The friable roof has the thickness of up to $0.2-0.35 \mathrm{~m}$, the roof is collapsed through the entire thickness.

The bottom of the seam is composed of argillites and siltstones of "curly" texture up to $1 \mathrm{~m}$ thickness with an ultimate compressive strength of $5.2-6.6 \mathrm{MPa}$. Below the rocks of "curly" texture, there are argillites, sometimes siltstones up to $15-23.0 \mathrm{~m}$, even lower sandstone up to $28 \mathrm{~m}$ thick.

In the area of the contoured reserves distribution of the 956 longwall face, the immediate roof of the seam $C_{9}$ is represented mainly by argillite of $1.0-10.8 \mathrm{~m}$, which is replaced by siltstone $(1.6-12.0 \mathrm{~m})$ and sandstone $(0.5-2.4 \mathrm{~m})$. The ultimate compressive strength of argillites is $\sigma_{c s}-11.2 \mathrm{MPa}$. The roof rocks are expected to be unstable and very unstable.

The main roof is composed of argillites, siltstones and sandstone. In terms of load properties, it is easily collapsed. The friable roof has the thickness of up to $0.2-0.32 \mathrm{~m}$, the roof is collapsed through the entire thickness.

The bottom of the seam is dominated by argillites with a thickness of $1.7-4.0 \mathrm{~m}$ and siltstones of $6.0-9.5 \mathrm{~m}$. The ultimate compressive strength of argillites is $\sigma_{c s}-11.2 \mathrm{MPa}$, siltstones $\sigma_{c s}-10.5 \mathrm{MPa}$.

The qualitative indicators of the mined coal seams in the "Named after Heroiv Kosmosu" mine are presented in Table 1.

Table 1. Qualitative indicators of the mined coal seams in the "Named after Heroiv Kosmosu" mine.

\begin{tabular}{|l|c|c|c|}
\hline \multicolumn{1}{|c|}{ Coal seam index } & $C_{11}$ & $\mathrm{C}_{10}{ }^{\mathrm{t}}$ & $\mathrm{C}_{9}$ \\
\hline Analytical humidity $W_{a}, \%$ & 2.4 & 2.3 & 2.2 \\
\hline Maximum humidity $W_{\max , \%} \%$ & 8.0 & 6.6 & 7.0 \\
\hline Parent ash $A_{m}, \%$ & 13.0 & 8.3 & 9.2 \\
\hline Total sulfur $S_{t}{ }^{d} \%$ & 2.0 & 1.5 & 2.0 \\
\hline Unit specific gravity of coal $\gamma, \mathrm{t} / \mathrm{m}^{3}$ & 1.2 & 1.2 & 1.16 \\
\hline Highest calorific value of combustible mass $Q_{s}{ }^{d a f}, \mathrm{MJ} / \mathrm{kg}$ & 33.1 & 34.1 & 35.3 \\
\hline Lowest calorific value of as-fired fuel $Q_{i}{ }^{r}, \mathrm{MJ} / \mathrm{kg}$ & 28.8 & 29.0 & 29.4 \\
\hline
\end{tabular}


Generalized characteristics of the stope faces, put into operation, of the "Named after Heroiv Kosmosu" mine, are presented in Table 2.

Table 2. Generalized characteristics of the stope faces, put into operation, of the "Named after Heroiv Kosmosu" mine

\begin{tabular}{|c|c|c|c|c|c|c|}
\hline $\begin{array}{c}\text { Longwall } \\
\text { face }\end{array}$ & $\begin{array}{c}\text { Coal } \\
\text { seam } \\
\text { index }\end{array}$ & $\begin{array}{c}\text { Stope equipment } \\
\text { (support, } \\
\text { shearer) }\end{array}$ & $\begin{array}{c}\text { Extraction } \\
\text { thickness } m_{r}, \mathrm{~m}\end{array}$ & $\begin{array}{c}\text { Stope face } \\
\text { length, } \mathrm{m}\end{array}$ & $\begin{array}{c}\text { Extraction } \\
\text { panel } \\
\text { length, } \mathrm{m}\end{array}$ & $\begin{array}{c}\text { Face } \\
\text { specified } \\
\text { load, } \mathrm{t} / \text { day }\end{array}$ \\
\hline 1121 & $C_{11}$ & \multirow{2}{*}{ 1KD90, KA200 } & \multirow{2}{*}{1.05} & 248 & 1600 & 2090 \\
\hline 1018 & $C_{10}{ }^{t}$ & & 250 & 1200 & 2135 \\
\hline 961 & $C_{9}$ & 1KD80, KA200 & & 243 & 1400 & 2103 \\
\hline
\end{tabular}

As it can be seen, according to the technological solutions of the mine, it is adopted to equip the stope faces with the widespread and tested in practice 1MKD90 and 1MKD80 mechanized complexes with KA-200 shearers. Based on the project of uncovering and preparation of the seams, the extraction panels will be mined according to the panel development system. As a rule, the panel development system allows, before to start the longwall face drivage, to perform a detailed additional exploration of the field area through the preparatory mine workings driven through the seam preliminary, which delineate the reserves of extraction panel.

Using the advantages of this mining system, during the preparation of new extraction panels, the authors of the work made a survey of the actual mine seams thickness. The survey method provided for the measurement of the real thickness of the outcropped coal seam along the contour of the preparatory mine working. The measurements were made in haulage and side mine workings along their length.

As a result of processing statistical information, graphs of changes in the geological thickness of seams $m_{g}$ have been obtained within the extraction panels contours, varying the value of out-of-seam rocks dilution $h_{r}$, as well as the predicted operational ash content in the stope faces $A_{o p}$.

The value $h_{r}$ of out-of-seam rocks dilution was determined as the difference between the minimum extraction thickness $m_{r}$ of the mechanized complex accepted for exploitation and the actual geological thickness of the seam $m_{g}$. Predicted operational ash content of coal $A_{o p}$ was calculated by the known expression using the method [30], taking into account the parent ash content of the seam $A_{m}$ according to the submitted mining-and-geological documentation. The data obtained as a result of processing are presented in graphical form in Fig. 4.

Based on the presented data, it follows that the geological thickness of the $C_{11}$ seam over the entire area of the extraction panel varies from 0.86 to 0.93 and averages $0.9 \mathrm{~m}$. The seam hypsometry is relatively consistent. Coal cutting resistance is $A p=275 \mathrm{kN} / \mathrm{m}$. According to the current development project, coal in the longwall face will be mined with out-of-seam dilution of bottom rocks, the minimum value of which will be $0.12 \mathrm{~m}$ and vary along the length of the extraction panel from 0.12 to $0.19 \mathrm{~m}$.

Coal of the $C_{11}$ seam refers to the mid-ash and according to geological information is on average $16 \%$. Assessing the data obtained, the predicted operational ash content of mined coal will average $45 \%$.

According to mining data, the $C_{10}{ }^{t}$ seam has a relatively sustained thickness, which varies along the length of the extraction panel from 0.82 to $0.91 \mathrm{~m}$ with an average dynamic of $0.85 \mathrm{~m}$. The seam is characterized by gently undulating bedding both along the dip and along the strike. The dip of the seam in the north-east direction is at an angle of $2-5^{\circ}$. Coal cutting resistance is $A p=420 \mathrm{kN} / \mathrm{m}$. The value of out-of-seam dilution in the longwall face is expected to be in the range of $0.19-0.23 \mathrm{~m}$. Coal of the $C_{10}{ }^{t}$ seam is low-ash $-9.3 \%$. The predicted operational ash content of the mined coal is expected to average $45.2 \%$. 
$a$

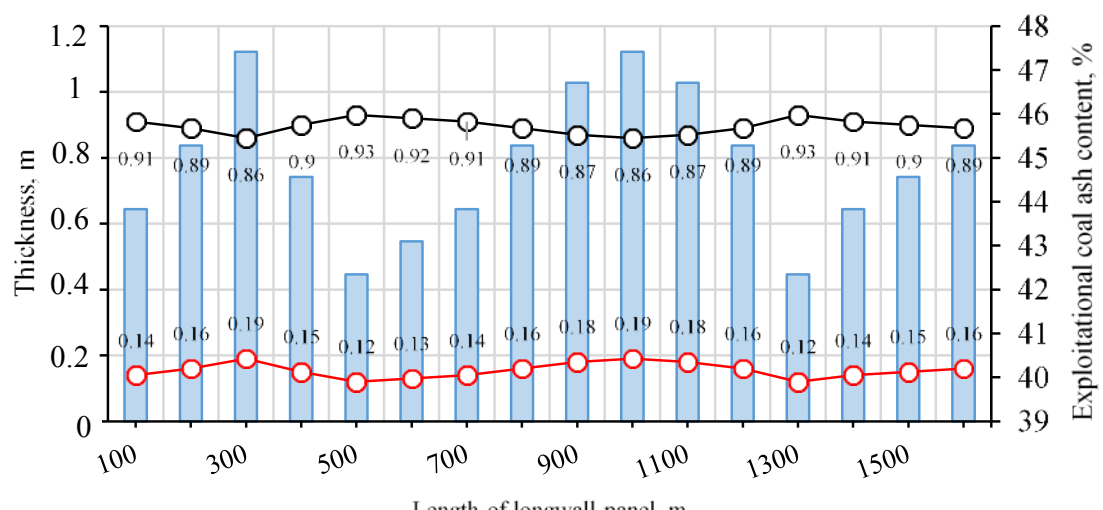

Length of longwall panel, $\mathrm{m}$

$b$

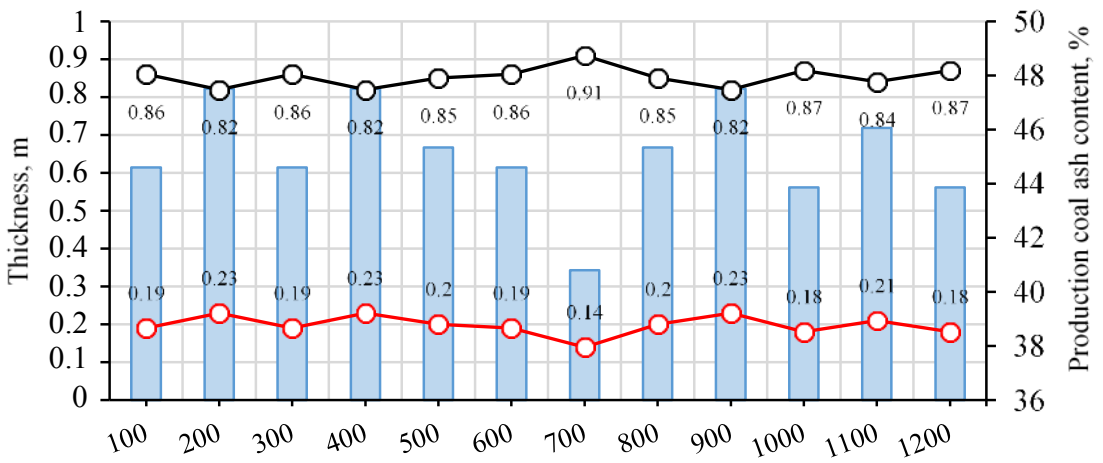

Length of longwall panel, $\mathrm{m}$

$c$

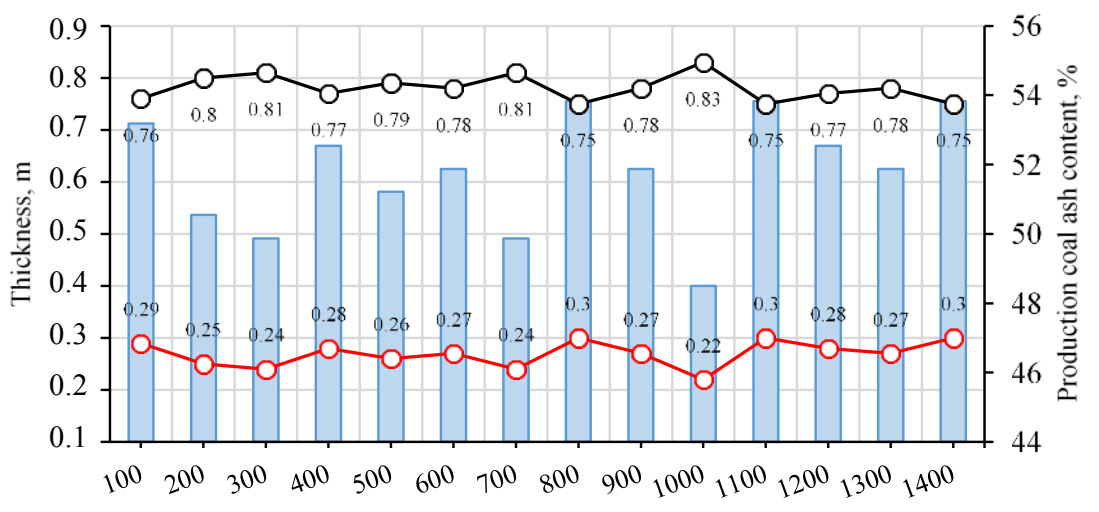

Length of longwall panel, $\mathrm{m}$

$\square$ production ash content $\longrightarrow$ - Coal seam thickness $\longrightarrow$ - out-of-seam dilution rock size

Fig. 4. Changes in geological thickness, value of out-of-seam rocks dilution and predicted production ash content in the mined seams within the extraction panels: $a$-across the $C_{11}$ seam; $b$-across the $C_{10}{ }^{t}$ seam, $c$-across the $C_{9}$ seam.

The $C_{9}$ seam is located below the $C_{10}{ }^{t}$ coal seam stratigraphically by $23 \mathrm{~m}$. On the area of the extraction panel location of the 961 longwall face, the coal seam has a relatively 
consistent geological thickness. Average dynamic seam thickness is $0.78 \mathrm{~m}$. Coal cutting resistance is $A p=390 \mathrm{kN} / \mathrm{m}$. The value of out-of-seam dilution in the longwall face will vary in the range from 0.22 to $0.30 \mathrm{~m}$, while providing the minimum extraction thickness value at the level of $1.05 \mathrm{~m}$. The $\mathrm{C}_{9}$ seam coal refers to the mid-ash $-12.3 \%$. The predicted operational ash content of mined coal is expected to average $51.4 \%$.

Based on the analysis performed, it follows that the stope faces put into operation within the studied extraction panels will operate with out-of-seam dilution of side rocks, and their greatest value is observed during mining the $C_{9}$ seam. The total operational ash content of the coal supplied from the longwall faces of the "Named after Heroiv Kosmosu" mine will account for $47.2 \%$.

The presented data indicate that for conditions of the "Named after Heroiv Kosmosu" mine new technologies are necessary for underground mining of coal deposits, which will allow to mine thin coal seams without coal dilution with waste rocks.

\section{Improving the quality of the mined thermal coal during the changeover to selective mining technology}

Analysis of coal-bearing rocks of the mined seams of the "Named after Heroiv Kosmosu" mine has revealed that unstable rocks, composed mainly of argillite and siltstone, occur in the roof of coal seams. Therefore, in order to reduce the collapse of rocks, selective mining of seams should be conducted with out-of-seam dilution of bottom rocks.

Average dynamic value of out-of-seam dilution of host rocks across the $C_{11}$ seam $0.16 \mathrm{~m}$; across the $C_{10}{ }^{t}$ and $C_{9}$ seams are 0.21 and $0.26 \mathrm{~m}$. Coal of the $C_{11}$ seam has an average cutting resistance of $275 \mathrm{kN} / \mathrm{m}$, the $C_{10}{ }^{t}$ and $C_{9}$ seams have 390 and $420 \mathrm{kN} / \mathrm{m}$.

Taking into account the listed geological characteristics for mining the 1121 longwall face of the $C_{11}$ seam, an extraction scheme is more rational, which provides for the initial extraction of the coal band across its entire thickness and the subsequent mining of out-ofseam rocks dilution. Considering that the coal of $C_{10}{ }^{t}$ and $C_{9}$ seams has a high cutting resistance, therefore it is more rational to perform the initial extraction of bottom rocks with a lower cutting resistance and the subsequent extraction of harder coal, which will be weakened by the presence of two outcropping cavities in the face.

When using a shearer with spaced auger executive bodies (such as UKD200, MV280E, LWS40/102 and their analogues), it is advisable to mine the seam with simultaneous extraction of coal and rock. In this case, in the conditions of mining the 1121 longwall face of the $C_{11}$ seam, it is advisable to destroy and load coal onto the conveyor with the front auger, and with the rear auger - extract the rock, leaving it on the seam bottom. Returning to another distinguished group of $C_{10}{ }^{t}$ and $C_{9}$ seams, it expedient in these geological conditions, to perform the first-priority extraction and loading of the bottom rock with the front auger, and, at the same time, with the rear auger to perform breaking of the coal band (in the roof).

Fig. 5 shows the graphs of the dependence of the predicted operational ash content of the produced coal depending on the adopted seam mining scheme and the value of the outof-seam dilution in the stope face.

From the presented data it follows that in the geological conditions of the $C_{9}$ seam, the changeover of the stope face from the complete mining to the selective mining of coal and out-of-seam dilution of rocks will reduce the operational ash content from 51.4 to $25.2 \%$ (with the scheme of combined selective seam mining) and up to $22 \%$ (with the sequential scheme). Similarly, when mining the $C_{10}{ }^{t}$ and $\mathrm{C}_{11}$ seams, the ash content of the mined coal can be reduced to 14.8 and $19.3 \%$, respectively, with the implementation of a sequential selective mining scheme. At the same time, comparing the obtained values of the predicted operational ash content of coal for different mining schemes, an increase in the out-of-seam 
dilution value by $0.1 \mathrm{~m}$, with a complete mining scheme, leads to an increase in ash content at an average by $5 \%$, with the scheme of combined selective mining by $1.0-1.5 \%$. With a sequential selective mining scheme in two passes of the shearer, an increase in the value of the out-of-seam dilution has practically no effect on the increase in the ash content of mined coal in the stope face. Thus, in the case of complete mining of coal seams, the out-of-seam dilution is more than twice as high as in the case of selective mining.

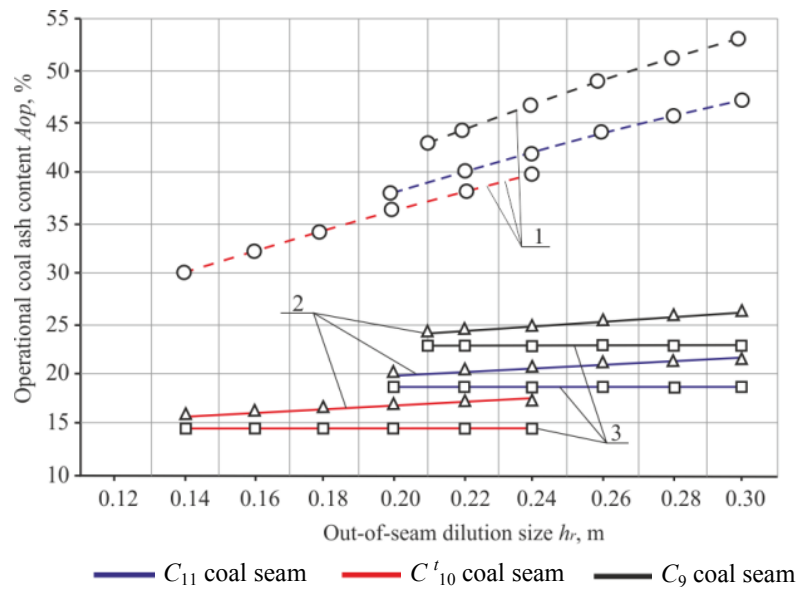

Fig. 5 Dependence of the predicted operational ash content of the produced coal on the adopted scheme for seam mining and the values of the out-of-seam dilution across the seams of the "Named after Heroiv Kosmosu" mine: 1 - scheme for complete mining; 2 - scheme for combined selective mining; 3 - scheme for sequential selective mining.

Therefore, the above analysis of the operational ash content indicates that in the conditions of modern production of the Western Donbas mines, there is a significant reserve for improving the quality of mined coal.

\section{Conclusions}

This paper provides a comprehensive assessment of the mining-technical conditions for the development and quality of coal mined in the Western Donbas mines. Using the example of the studied region mines and analyzing the stope faces efficiency, the tendencies have been revealed of the change in the operational and parent ash content of coal, the number of longwall faces working with out-of-seam dilution and output volumes, which leads to worsening the quality of the produced thermal coal.

In the course of the research, a number of features and results have been revealed:

- coal mining in the Western Donbas is carried out in difficult mining-and-geological conditions with an average geological thickness of $0.81 \mathrm{~m}$, which negatively affects the quality of the produced thermal coal;

- for the period 2000-2019, the operational ash content of mined coal increased by 3.5 to $44.3 \%$. Currently, $90 \%$ of mining in the region comes from the stope faces, which operate in seams with a geological thickness of less than $1.0 \mathrm{~m}$;

- for the period under review, the output volumes of raw coal increase from 15.0 to 18.2 million tons per year, or by $15.5 \%$. Moreover, the number of longwall faces working with out-of-seam dilution of rocks has increased. The total ratio of number of the longwall faces working with out-of-seam dilution of rocks to the total number of longwall faces is $82 \%$ (+9\% compared to 2019$)$; 
- over the past 2019, 26 extraction panels were mined, while only 7 longwall faces carried out mining practically without out-of-seam rocks dilution in seams with thickness from 1.0 to $1.22 \mathrm{~m}$;

- the widespread use of complete mining technology in stope faces, working with outof-seam dilution of side rocks, significantly increases the general ash content of the rock mass to $42-45 \%$, and at some enterprises up to $50 \%$ ("Named after Heroiv Kosmosu" mine);

- the detailed analysis of coal-bearing rocks within the boundaries of the contoured reserves of the new extraction panels of the $C_{11}, C_{10}{ }^{t}$ and $C_{9}$ seams in the "Named after Heroiv Kosmosu" mine made it possible to preliminary assess the possibility of using the selective mining technology;

- taking into account such characteristics as geological thickness of coal seams, coal cutting resistance, immediate roof stability and bottom strength, the preferred options for schemes selective coal mining the $C_{11}, C_{10}{ }^{t}$ and $C_{9}$ seams in the "Named after Heroiv Kosmosu" mine have been selected;

- the dependences of the change in the predicted operational ash content on the options of schemes for the seams mining and the values of out-of-seam dilution of rocks obtained from the research results made it possible to determine that in the geological conditions of the $C_{9}$ seam the changeover of the stope face from the complete mining to the selective mining of coal will reduce the operational ash content from 51.4 to $25.2 \%$ (with the scheme of combined selective seam mining) and up to $22 \%$ (with the sequential scheme). Similarly, when mining the $C_{10}{ }^{t}$ and $C_{11}$ seams, the ash content of the mined coal can be reduced to 14.8 and $19.3 \%$, respectively, with the implementation of a sequential selective mining scheme.

The results of the work were obtained within the framework of the research projects "Development of advanced technologies for complete extraction of thermal coal with accumulation of waste rocks in the underground space" (State registration No. 0120U101099).

\section{References}

1. Coal Information: Overview. Paris. (2019). Retrieved from https://www.iea.org/reports/coalinformation-2019

2. BP Statistical Review of World Energy. (2019). Retrieved from https://www.bp.com/content/dam/bp/business-sites/en/global/corporate/pdfs/energyeconomics/statistical-review/bp-stats-review-2019-full-report.pdf

3. Cornot-Gandolphe, S. (2019). Status of Global Coal Markets and Major Demand Trends in Key Regions. Germany. Retrieved from https:/www.ifri.org/sites/default/files/atoms/files/cornotgandolphe_global_coal_market_2019.pdf

4. Wang, Q., Song, X., \& Liu, Y. (2020). China's coal consumption in a globalizing world: Insights from Multi-Regional Input-Output and structural decomposition analysis. Science of The Total Environment, (711), 134790. https://doi.org/10.1016/j.scitotenv.2019.134790

5. Kovalevska, I., Zhuravkov, M., Chervatiuk, V., Husiev, O., \& Snihur, V. (2019). Generalization of trends in the influence of geomechanics factors on the choice of operation modes for the fastening system in the preparatory mine workings. Mining of Mineral Deposits, 13(3), 1-10.

6. Sribna, Y., Trokhymets, O., Nosatov, I., \& Kriukova, I. (2019). The globalization of the world coal market - contradictions and trends. E3S Web of Conferences, (123), 01044. https://doi.org/10.1051/e3sconf/201912301044

7. Wen, L. (2015). Shenhua's Evolution From Coal Producer to Clean Energy Supplier. Cornerstone, 3(1), 10-14.

8. Wiatros-Motyka, M. (2016). An overview of HELE technology deployment in the coal power plant fleets of China, EU, Japan and USA. London: IEA Clean Coal Centre, 75.

9. Wang, S. (2020). Near-Zero Air Pollutant Emission Technologies and Applications for Clean Coal-Fired Power. Engineering. https://doi.org/10.1016/j.eng.2019.10.018 
10. Pssarenko, M.V. (2016). Gorno-geometricheskoe obespechenie otsenki podgotovlennosti mestorozhdeniya k osvoeniyu po pokazatelyu zol'nosti uglya. Gornaya Promyshlennost', 1(125), 62-64.

11. Snihur, V., Malashkevych, D., \& Vvedenska, T. (2016). Tendencies of coal industry development in Ukraine. Mining of Mineral Deposits, 10(2), 1-8. https://doi:10.15407/mining10.02.001

12. Bahri Najafi, A., Saeedi, G.R., \& Ebrahimi Farsangi, M.A. (2014). Risk analysis and prediction of out-of-seam dilution in longwall mining. International Journal of Rock Mechanics and Mining Sciences, (70), 115-122. https://doi.org/10.1016/j.ijrmms.2014.04.015

13. Ermekov, T.E., Issabek, T.K., \& Issabekov, E.T. (2016). Mining robotic complex with adaptive control software (mrcacs). Naukovyi Visnyk Natsionalnoho Hirnychoho Universytetu, (4).

14. Ralston, J.C., \& Strange, A.D. (2013). Developing selective mining capability for longwall shearers using thermal infrared-based seam tracking. International Journal of Mining Science and Technology, 23(1), 47-53. https://doi.org/10.1016/j.ijmst.2013.01.008

15. Kosarev, I.V. (2016). Innovatsionnye napravleniya v sozdanii gorno-shakhtnogo oborudovaniya, obespechivayushchego povyshenie effektivnosi dobychi uglya. Vestnik Donetskogo Natsional'nogo Tekhnicheskogo Universiteta, (6), 12-18.

16. Pavlenko, I., Salli, V., Bondarenko, V., Dychkovskiy, R., \& Piwniak, G. (2007). Limits to Economic Viability of Extraction of Thin Coal Seams in Ukraine. Technical, Technological and Economical Aspects of Thin-Seams Coal Mining. International Mining Forum, 2007, 129-132. https://doi.org/10.1201/noe0415436700.ch16

17. Sokolov, A.S., \& Potapov, V.V. (2014). Tekhniko-ekonomicheskaya effektivnost' tekhnologii podzemnogo ugleobogashcheniya. Izvestiya Vuzov. Gornyy Zhurnal, (1), 42-46.

18. Potapov, V.V., Feklistov, Yu.G., Vandyshev, A.M., \& Potapov, V.Ya. (2006). Tekhnologicheskie skhemy upravleniya kachestvom uglya pri podzemnoy dobyche po friktsionnym kharakteristikam. Gornyy Informatsionno-Analiticheskiy Byulleten', (5).

19. Bondarenko, V.I., Russkikh, V.V., Malashkevich, D.S., \& Sotskov, V.A. (2017). Tekhnologicheskaya skhema i oborudovanie dlya selektivnoy dobychi uglya dlinnymi ochistnymi zaboyani. Visti Donetskoho Hirnychoho Instytutu, 2(41), 19-24.

20. Byzylo, V., Koshka, O., Poymanov, S., \& Malashkevych, D. (2015). Resource-saving technology of selective mining with gob backfilling. New Developments in Mining Engineering 2015: Theoretical and Practical Solutions of Mineral Resources Mining, 485-491. https://doi.org/10.1201/b19901-84

21. Buzylo, V.I., Koshka, O.H., Yavorskyi, A.V., Yavorska, O.O., Tokar, L.A., Sulaiev, V.I., \& Serdiuk, V.P. (2015). Selective mining technique for thin coal seams. Dnipropetrovsk: Natsionalnyi Hirnychyi Universytet, 132.

22. Koshka, O., Yavors'kyy, A., \& Malashkevych, D. (2014). Evaluation of surface subsidence during mining thin and very thin coal seams. Progressive Technologies of Coal, Coalbed Methane, and Ores Mining, 229-233. https://doi.org/10.1201/b17547-41

23. Malashkevych, D., Sotskov, V., Medyanyk, V., \& Prykhodchenko, D. (2018). Integrated Evaluation of the Worked-Out Area Partial Backfill Effect of Stress-Strain State of Coal-Bearing Rock Mass. Solid State Phenomena, (277), https://doi.org/10.4028/www.scientific.net/ssp.277.213

24. Sotskov, V.O., Podvyhina, O.O., Dereviahina, N.I., \& Malashkevych, D.S. (2018). Substantiating the criteria for applying selective excavation of coal deposits in the Western Donbass. Journal of Geology, Geography and Geoecology, 26(1), 158-164. https://doi.org/https://doi.org/10.15421/111817

25. Kurs na enerhonezalezhnist: shakhtari DTEK Enerho dobuly bilshe 22 mln tonn vuhillia za 2019 rik. (2019). Retrieved from https://energo.dtek.com/media-center/press/kurs-naenergonezavisimost-shakhtery-dtek-energo-dobyli-bolshe-22-mln-tonn-uglya-za-2019-god/

26. Bondarenko, V., Cherniak, V., Cawood, F., \& Chervatiuk, V. (2017). Technological safety of sustainable development of coal enterprises. Mining of Mineral Deposits, 11(2), 1-11. https://doi.org/10.15407/mining11.02.001

27. SOU 10.1.00185755.001-2004. (2004). Vuhillia bure, kamiane ta antratsyt. Metodyka rozrakhunku pokaznykiv yakosti. Kyiv: Minpalyvenerho Ukrainy. 